\title{
VALUE OF HEALTH FOR TRUE HAPPINESS IN CORONACRISIS
}

In Happiness And Contemporary Society : Conference Proceedings Volume (Lviv, March, 20-21, 2021). Lviv: SPOLOM, 2021. P. 251-253. https://doi.org/10.31108/7.2021.55

ISBN 978-966-919-697-2

\section{ЦІННІСТЬ ЗДОРОВ'Я ДЛЯ СПРАВЖНЬОГО ЩАСТЯ В КОРОНАКРИЗІ}

// Щастя та сучасне суспільство : збірник матеріалів міжнародної наукової конференції (Львів, 20-21 березня 2021 р.). - Львів : СПОЛОМ, 2021. С. 251-253. https://doi.org/10.31108/7.2021.55

ISBN 978-966-919-697-2 


\title{
ROMANYUK Lyudmyla
}

Doctor of Sciences in Psychology, Professor of the psychology and sociology Department, University of the State Fiscal Service of Ukraine (Ukraine)

\author{
SHEVCHENKO Andriy \\ student (Bachelor's level) \\ University of the State Fiscal Service of Ukraine (Ukraine)
}

\section{VALUE OF HEALTH FOR TRUE HAPPINESS IN CORONACRISIS}

The purpose of this research is to find an understanding of the relationship between the values of health and happiness. Authors based on positive psychology in the understanding of happiness as the ability to be happy, which includes: a positive worldview, mastery of the technique of mental stability, active use of the keys to happiness. By managing the keys to happiness that one can create internal preconditions for the becoming of socially attractive interests and values in a human's personality, because by imposing the keys to happiness on certain values of life, he (she) begins to experience happiness from advancing social values or constructing new positive values, which lead to happiness.

Key words: positive values, happiness, health.

РОМАНЮК Людмила

доктор психологічних наук, професор, професор кафедри психології та сочіології Університету Державної Фіскальної Служби Украӥни (Украӥна)

ШЕВЧЕНКО Андрій

здобувач вищої освіти першого (бакалаврського) рівня

Університету Державної Фіскальної Служби Украӥни (Украӥна)

\section{ЦІННІСТЬ ЗДОРОВ’Я ДЛЯ СПРАВЖНЬОГО ЩАСТЯ В КОРОНАКРИЗІ}

“Володіти... благами - це ще не все. Отримувати насолоду від володіння ними - ось у чому полягає щастя” Марк Тулій Цицерон [1].

Питання про те, що є щастя, та як бути по-справжньому щасливою людиною актуальне протягом тисячоліть. Нині, коли людина володіє цивілізаційними благами, особливо значущою виступає необхідність забезпечення належного рівня медицини, та охорона здоров'я, що часто корелюють із усіма аспектами людського щастя. Особливо актуалізувалася цінність здоров'я та його забезпечення завдяки належній медицині під час світової епідемії коронавірусу, а саме, щастя бути здоровим, мати імунітет до вірусів - $є$ вже “спражнім щастям" нині. Варто зазначити, що поняття “щастя” є суб' єктивним явищем, а розуміння “щаслива 
людина - здорова людина" є актуальним завжди, бо в здоровому тілі - здоровий дух, а отже, й справжнє щастя.

Метою цієї розвідки є пошук розуміння взаємозв'язків між цінностями здоров'я й щастя.

Дослідженню кореляцій між щастям людини та її здоров'ям присвячені праці науковців, серед яких особливу увагу привертають дослідження професора Л. Романюк $[5 ; 6]$, яка разом із своїми учнями підтримує й розвиває позитивну психологію у її розумінні щастя як уміння бути щасливим, яке включає: позитивне світосприйняття, володіння технікою душевної стійкості, активне використання ключів щастя. Саме керуючи ключами щастя, можна створювати внутрішні передумови для становлення в особистості людини соціально привабливих інтересів і цінностей, оскільки, накладаючи ключі щастя на ті чи інші цінності життя, вона починає переживати щастя від просування по вже заданих соціальних цінностях, або конструювати нові позитивні цінності, які ведуть до щастя [5].

Важливу роль для переживання щастя відіграє психічне здоров'я, що проявляється насамперед у суб'єктивному (психологічному) благополуччі. Воно визначається не тільки відсутністю певних психічних захворювань або розладів, а й рядом соціально-біологічних, соціально-економічних та решти факторів, котрі мають вплив на сучасне навколишне середовище, та навколишні фактори [3]. Психічно здорова людина, завжди знає, до чого вона прагне, та чого жадає. Вона формує у собі якості життєрадісної, веселої та сповненої натхнення, що є одними із найголовніших показників щастя.

Беручи до уваги дослідження світового індексу щастя населення та рівня щастя в Україні, ми бачимо значні коливання, зміни та відмінності у показниках статистичних даних. Слід відмітити, що шляхом проведення соціального опитування у більшості країн світу 54 \% ті, котрі відчувають себе по-справжньому щасливими, а 14 \% вважають себе нещасними. Розглядаючи статистику в Україні за останній 2020-й рік, бачимо, що цей показник є значно нижчим порівняно 3 світовим, але у порівнянні з 2019-м роком, коли він становив $33 \%$, й 3 нинішніми $14 \%$, а також з $8 \%$ 2018-го року, він є значно вищим. Кількість "щасливого населення" дорівнює 49 \% від усього його числа, а “нещасливого” - 35 \% від його загальної кількості [4].

Резюмуючи все вище проаналізоване, можна констатувати, що кожна людина завдяки рефлексії самодослідження своїх цінностей, робить сама для себе висновки, формуючи власне розуміння того, що зробить іï щасливою. Отже, відчуття людиною щастя суб'єктивно пов'язане з їі цінностями й, насамперед, із цінностю здоров'я в нинішній коронакризі.

\section{ЛІТЕРАТУРА}

1. Що таке щастя ? Вислови видатних людей про щастя. Електронний ресурс: Блогспорт. URL : http://yfnfksz5.blogspot.com/p/blog-page_30.html

2. Петров С.Ю. ЦІННІСТЬ ЗДОРОВ'Я ОСОБИСТОСТІ ЯК ОБ'ЄКТ ФІЛОСОФСЬКОГО ПІЗНАННЯ. Електронний ресурс : Нова парадигма. 112. Національний Педагогічний Університет М.П. Драгоманова URL : http://enpuir.npu.edu.ua/bitstream/123456789/8860/1/Putrov\%20S..pdf 
3. Психічне здоров'я - основа щасливого життя людини. Електронний ресурс : Блог медичного иентру сімейної допомоги. URL https://brovmedcentr.in.ua/2018/10/09/\%D0\%BF\%D1\%81\%D0\%B8\%D1\%85\%D1 \%96\%D1\%87\%D0\%BD\%D0\%B5\%D0\%B7\%D0\%B4\%D0\%BE\%D1\%80\%D0\%BE\%D0\%B2\%D1\%8F\%D0\%BE\%D1\%81\%D0\%BD\%D0\%BE\%D0\%B2\%D0\%B0\%D1\%89\%D0\%B0\%D1\%81\%D0\%BB\%D0\%B8\%D0\%B2\%D0\%BE\%D0\%B3/

4. Індекс щастя: Україна опинилася у п'ятірці найбільш нещасливих країн світу. Електронне видання : СуспЛайнМедіa. 2021. URL : https://suspilne.media/95774indeks-sasta-ukraina-opinilasa-u-patirci-najbils-nesaslivih-krain-svitu/

5. Романюк Л. Становлення цінностей особистості: психологічний аспект. Кам'янецьПодільський. С. 91-108.

6. Романюк Л. ПСИХОЛОГІЯ ЩАСТЯ В КОНТЕКСТІ ЦІННОСТЕЙ ОСОБИСТОСТІ / Л.РОМАНЮК, І.БОРЩАК, О.МАЦЮК // Щастя та сучасне суспільство : збірник матеріалів міжнародної наукової конференції (Львів, 2021 березня 2020 р.). - Львів: СПОЛОМ, 2020. - С. 217-219. https://doi.org/10.31108/7.2020. I/http://ukr-happiness-institute.com/wpcontent/uploads/2020/03/217_romaniuk-1.pdf 